\title{
Stratigraphy of the Dokan Formation (Upper Cretaceous) Jebel Azmer- Sulaimaniya Area, Northeastern Iraq
}

\author{
Tarik S. Abawi \\ Department of Geology \\ College of Science \\ Mosul University
}

\author{
Rund A. Hammoudi \\ Department of Biology \\ College of Science \\ Dohuk University
}

(Received 6/11/2008, Accepted 16/8/2009)

\begin{abstract}
Contrary to the present opinion regarding the Balambo Formation exposed in Jebel Azmer, Sulaimaniya area, northeastern Iraq, this study shows that the upper part $(63 \mathrm{~m})$ of the Balambo succession actually belongs to the Dokan Formation. The major hiatus between the lower part of the succession which represents the Balambo Formation and the upper part of the succession which we claim to represent the Dokan Formation together with the lithological differences give strong reason to characterize the studied section as the Dokan Formation.

Dokan Formation in the studied section consists of light brown and white massive not well bedded limestone. Nineteen planktonic foraminiferal species have been identified from this section. The age of the Dokan Formation in the Jebel Azmer area is Middle - Late Cenomanian and is assigned to Rotalipora cushmani Zone; this indicates a major hiatus between the Dokan Formation and the older Balambo Formation of Middle-Late Albian age in this area.
\end{abstract}




\section{طباقية تكوين دوكان (الكريتاسي الأعلى) في جبل أزمر - منطقة السليمانية شمال شرق العرلق}

$$
\text { قلد علبة علي حمودي العلوم }
$$

$$
\text { طارق صالح عباوي علبة العلوم الأرض }
$$

\section{الملخص}

أنتبت الدراسة الحالية ان الجزء العلوي ( با منرا) من تكوين بلامبو المنكشف في جبل أزمر في

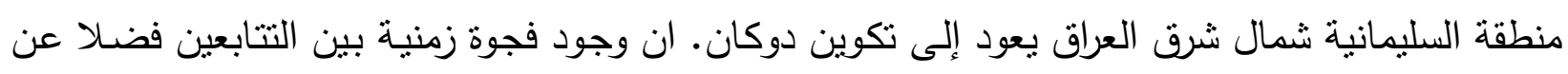

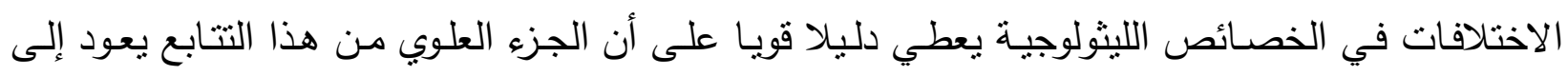
تكوين دوكان.

يتألف تكوين دوكان في مقطع الدراسة من صخور الحجر الجيري البني والأبيض الكتلي وقليل التطبق. تم تشخيص تسعة عشر نوعا من الفورامنيفرا الطافية في مقطع هذا التكوين. عمرالتكوين في مقطع الدراسة

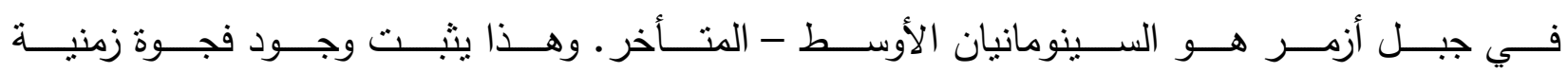
كبيرة مع تكوين بلامبو الأقدم والذي يعود عمره إلى الالبيان الأوسط - المتأخر . 